504.053

\author{
- int y \\ ьвівський н ціон льний університет імені в н \\ вул. . орошенк , 41, м. ьвів, 79000, кр їн
}

исвітлено структуру основних к тегорій земель рп тського регіону. бгрунтов но тенденції змін земель різного скл ду т цільового призн чення.

лючові слов : рп тський регіон, земельний фонд, к тегорії земель, сільськогоспод рські угіддя, рілля, ліси, з будов ні ділянки.

ля кр їни земля є основним н ціон льним б г тством, що перебув є під особливою охороною держ ви. емлі кр їни м ють н дзвич йно високий рівень освоєння. одноч с у суч сних умов х землекористув ння сформов н структур земельних угідь т їхнє просторове розміщення (здебільшого, п рцелярні прямокутні господ рські межі) не повністю відповід ють вимог м р ціон льного природокористув ння. ростежене недост тнє соці льне, економічне й екологічне обгрунтув ння розподілу земель 3 цільовим призн ченням, особливо в ході проведення земельної реформи т перерозподілу вл сності.

тегорії земель рп тського регіону кр їни з основним цільовим призн ченням висвітлено у пр цях . іпт ч (2008) і . ньків (2008), кл сифік ційні д ні розподілу к тегорій земельних угідь у розрізі територі льно- дміністр тивних одиниць - у форм х (т блицях) ст тистичних збірників “ егіони кр їни”.

б'єктом н шого дослідження є скл д т цільове призн чення земель рп тського регіону кр їни. ет - н ліз еколого-ст тистичних д них скл ду т цільового призн чення земель, оцінк рівня їхнього освоєння, т кож укл д ння к рт-схем рейтингу обл стей рп тського регіону з площею основних к тегорій земель серед регіонів кр їни.

емлі рп тського регіону м ють високий рівень освоєння. ро це свідчить н ліз еколого-ст тистичних досліджень структури земельного фонду регіону [5, с. 321; 8, с. 183-187]. окрем , ст ном н 1 січня 2007 р. земельний фонд регіону ст новив 5 660,7 тис. г , бо 9,4 \% від з г льної площі території кр їни. його структурі землі сільськогоспод рського призн чення з йм ли 2 900,9 тис. г (51,2 \% від з г льної площі регіону), що н $19,9 \%$ менше, ніж середнє зн чення для кр їни. володінні т користув нні всіх к тегорій господ рств перебув ло 2 411,3 тис. г (83,1 \% від площі земель сільськогоспод рського призн чення) сільськогоспод рських угідь, решту 489,6 тис. г (16,9 \%) 3 йм ли несільськогоспод рські угіддя; 1 612,8 тис. г (66,9 \%) сільськогоспод рських угідь було розор но, у тім числі 80,8 \% (1 302,7 тис. г ) з сіяно сільськогоспод рськими культур ми, що ст новило 55,6 \% земель сільськогоспод рського призн чення. ихідні д ні структури земельного фонду регіону з свідчують, що н йбільш питом

(C) іпт ч ., 2010 
в г розор них земель у ернівецькій (40,7 \% від з г льної площі обл сті), ьвівській $(33,4 \%)$ т в но- р нківській $(25,8 \%)$ обл стях (в 0,8-0,5 р з менш від середньої для кр їни $(51,0 \%))$, н йменш -у к рп тській $(15,3 \%)$. орівняно з 1990 р. площ сільськогоспод рських угідь у володінні т користув нні всіх к тегорій господ рств зменшил ся н 236,2 тис. г $(8,9 \%)$ [7, с. 174; 8, с. 183], ріллі - н 177,6 тис. г (9,9\%) [7, c. $177 ; 8$, с. 186], н йбільше цих угідь втр тил ьвівськ обл., зокрем : сільськогоспод рських угідь $-209,2$ тис. г $(16,6 \%)$, ріллі - 135,8 тис. г $(15,7 \%)$. ейтинг обл стей

рп тського регіону з площею основних к тегорій земель серед регіонів кр їни висвітлено н рис. 1-4.

ісовою рослинністю вкрито 40,9 \% (2 312,4 тис. г ) земель рп тського регіону [5, с. 321]. н ліз ст тистичних д них свідчить, що н йбільші площі їх є в к рп тській $(56,8 \%$ від з г льної площі обл сті) т в но- р нківській $(45,7 \%)$ обл стях, дещо менші - у ьвівській $(31,8 \%)$ і ернівецькій $(31,8 \%)$. тже, питом в г цих земель у регіоні зн чно вищ порівняно із середньою для кр їни $(17,5 \%)$. г льний з п с деревост нів оцінено в 0,5 млрд м ${ }^{3}$, середній приріст н 1 г ст новить $4,4 \mathrm{~m}^{3}$ [1]. дн к швидкими темп ми н рощують з готівлю ліквідної деревини, особливо в в ноківській, ьвівській і ернівецькій обл стях. прикл д, у 2006 р. в регіоні з готовлено 3789,2 тис. ${ }^{3}$ (н 36,9 \% більше, ніж 2000 р.) деревини, зокрем , у ьвівській обл. 1 126,9 тис. м $^{3}$ (н 45,6 \%), у к рп тській - 1010,0 (н 11,4\%), в в но- р нківській 826,3 (н 59,5 \%), ернівецькій - 826,0 тис. м³ (н 45,1 \%) [8, с. 245]. дноч сно зі щор 3 більшими обсяг ми з готівлі деревини зн чно збільшується площ лісовідновлюв льних земель. 2006 р. н землях лісогоспод рського призн чення було відновлено 12721 г лісів, у тім числі: у ьвівській обл. 4411 г, в но- р нківській 2 978, к рп тській - 2852 , ернівецькій - 2480 г [8, с. 246]. підст ві н лізу ст тистичних д них стосовно ведення лісового господ рств можн дійти т ких висновків: nо-перше, зрост ють темпи т обсяги з готівлі ліквідної деревини; по-друге, зн чно збільшується площ лісовідновлюв льних земель; по-третє, порушується оптим льне співвідношення структури вікових груп лісів. ерев ж ють молодняки, різко зменшуються площі середньовікових, пристиг ючих і стиглих вікових груп. родовжуються суцільні лісовідновлюв льні рубки всупереч лісогоспод рським з ход м, які спрямов ні н формув ння високопродуктивних і стійких лісост нів з високими екологічними т $з$ хисними функціями.

ілянки під з будовою розміщено н 251,7 тис. г , що ст новить 4,4 \% від з г льної площі земель регіону [5, с. 321]. цих земельних ділянк х збудов но 81 місто, 85 селищ міського типу і 3592 сільські н селені пункти. окрем , у ьвівській обл. розміщено 44 міст , 34 селищ міського типу і 1850 сільських н селених пунктів; в в но-

p нківській - відповідно, 15, 24, 765, у к рп тській - 11, 19, 579, у ернівецькій 11, 8, 398 [3, с. 10]. н ліз ст тистично-довідкових д них з свідчив, що н йбільше 3 будов ними є землі ьвівської обл. (5 \% від з г льної площі обл сті). кщо до 2000 р. площі з будов них земельних ділянок у регіоні поступово збільшув лися, головно 3 земель сільськогоспод рського призн чення, то вже впродовж ост нніх років ситу ція $з$ відведенням ділянок під з будову дещо ст білізув л ся. окрем, порівняно з 2003 р. [4, с. 486] площі з будов них ділянок збільшилися, перев жно, н землях ьвівської (н 0,4 тис. г ) і ернівецької (н 0,7 тис. г ) обл стей [5, с. 321]. кщо про н лізув ти територі льний спект з будови як лімітув льний чинник, то це дуже в жливо для гірських територій кр їнських рп т, н рівнинній ч стині обл стей $є$ прин ймні три-п’ятир зовий з п с площ, прид тних для виокремлення ділянок під з будову. 


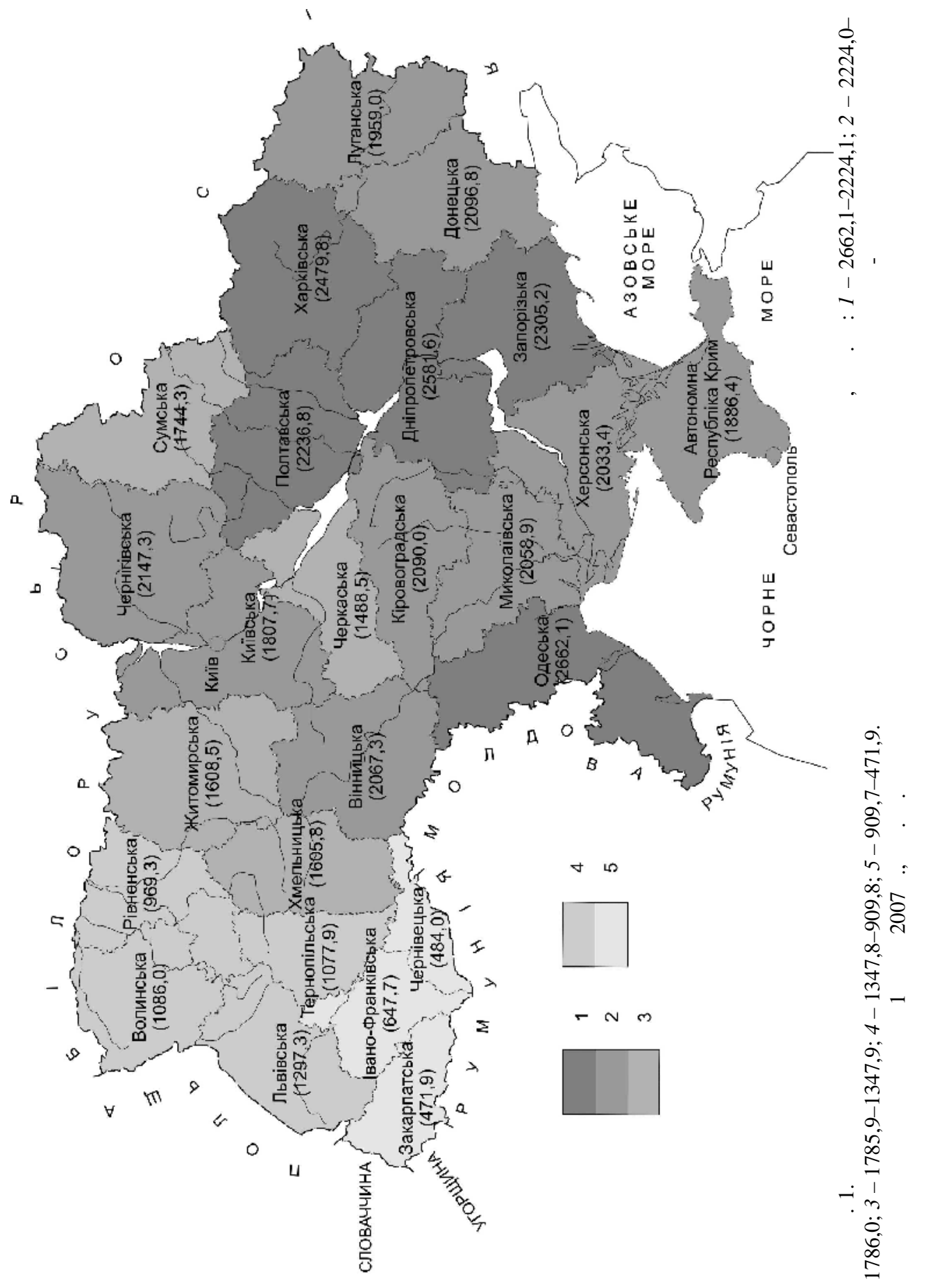




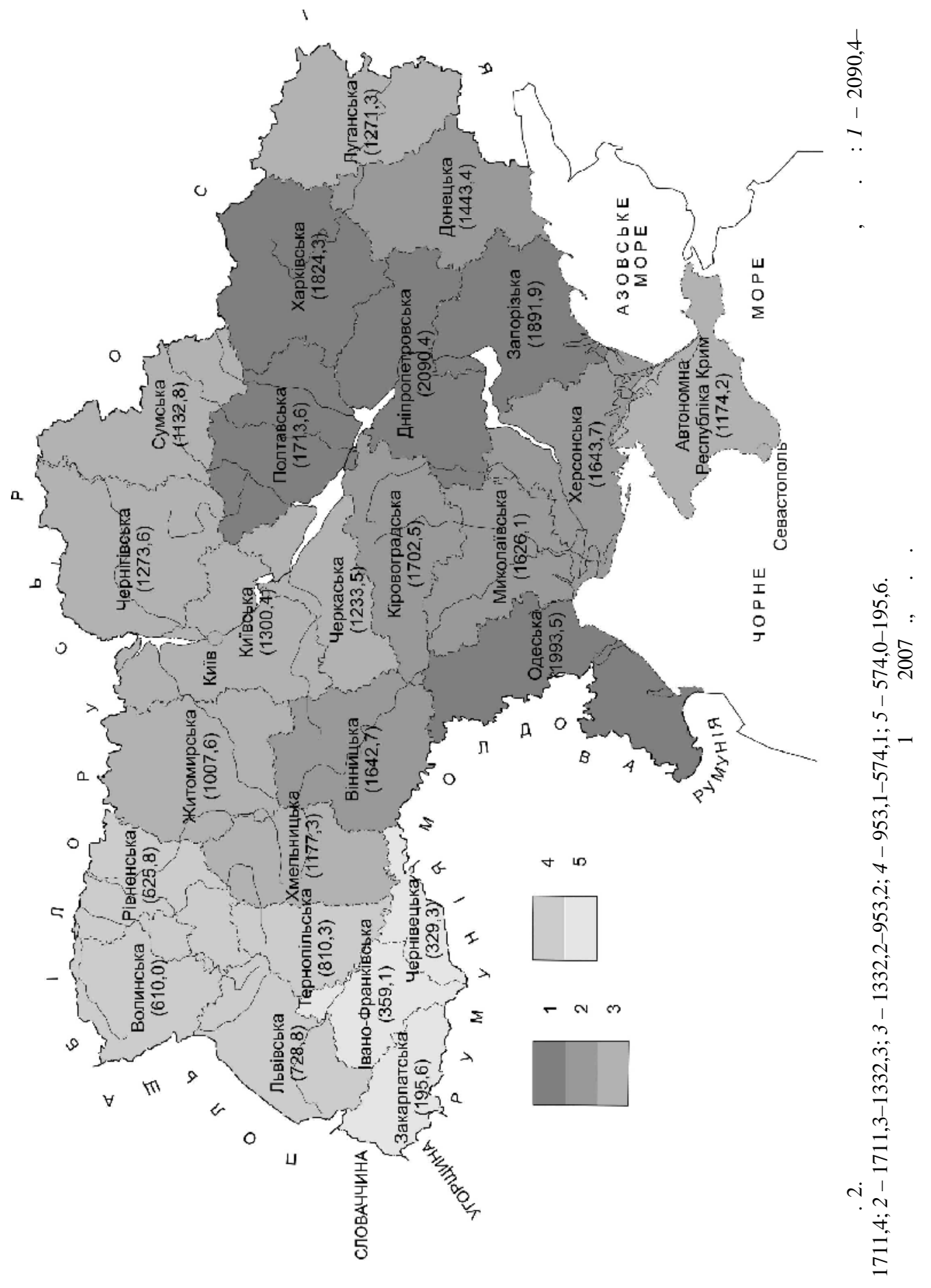




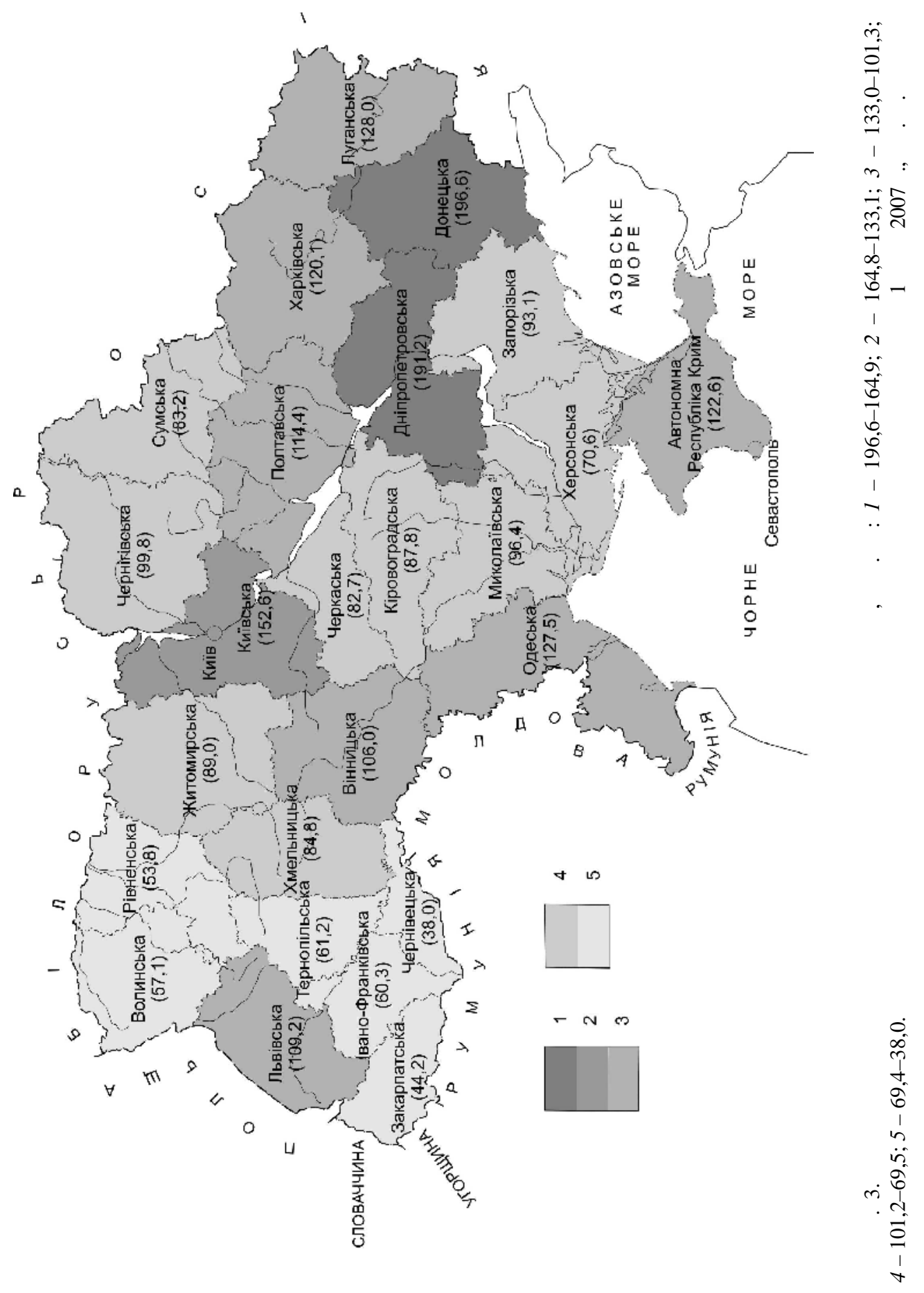




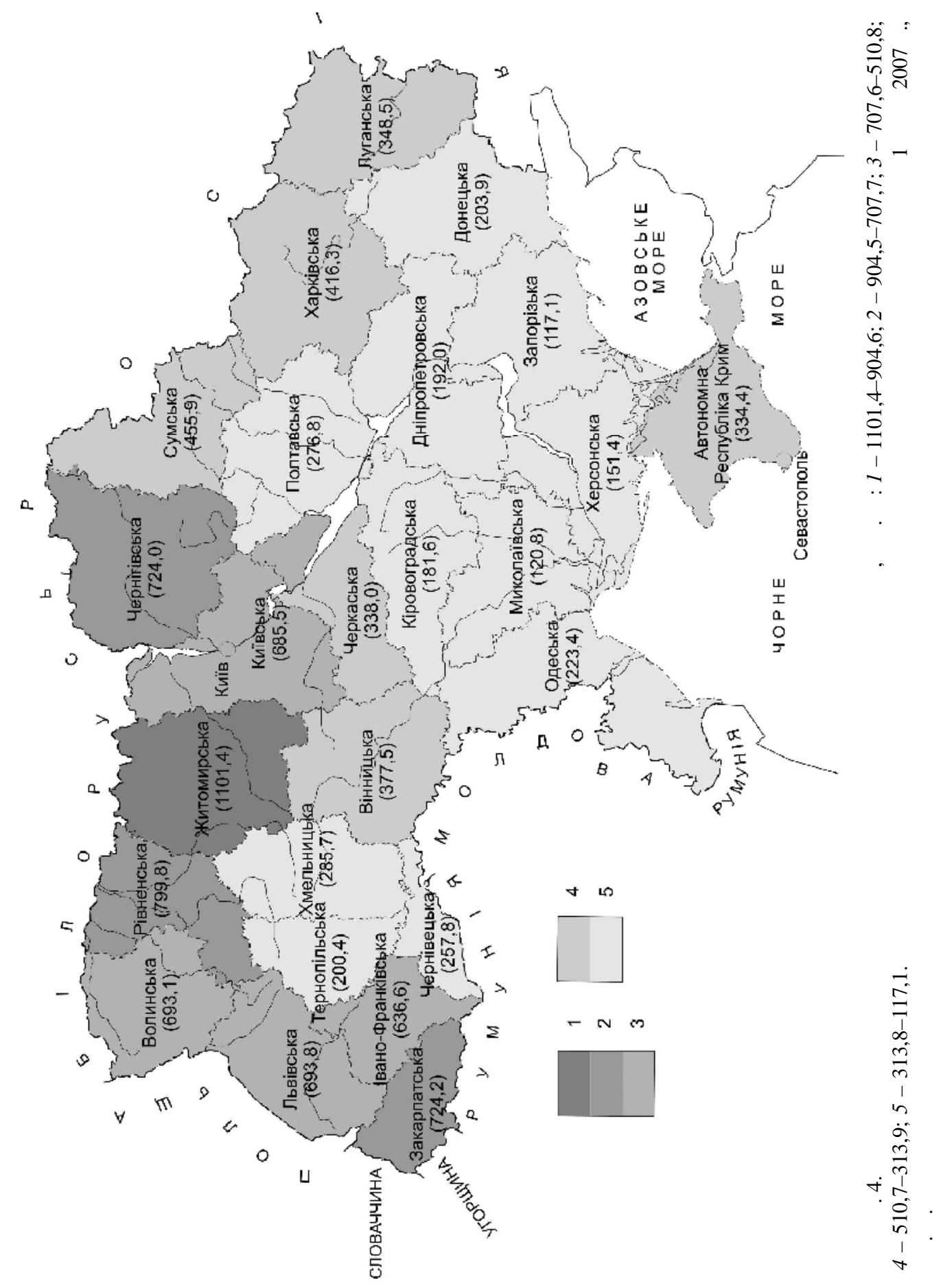


стин (103,2 тис. г ) земель регіону є під водою (1,8 \% від з г льної площі регіону) і вкрит болот ми $(0,25 \%)$ [5, с. 321]. к виплив є зі структури земель цих к тегорій, рп тський регіон н лежить до норм льно і н йбільш зволожених регіонів кр їни. окрем , 3 ст ном н 1 січня 2007 р. землі під водою і відкриті з болочені землі з йм ли 2,4 \% від з г льної площі цієї к тегорії земель у ьвівській і ернівецькій обл стях, відповідно, 1,5 і 1,9\% у к рп тській т в нов ж ючи н розвинену мережу природних і штучних водних об'єктів, кту льною серед екологічних проблем сьогодення, головно рівнинної території водних б сейнів регіону, є проблем якісної води.

ешту території регіону з йм ють інші землі. йбільше їх в в но- р нківській $(1,6 \%)$ і ьвівській $(1,4 \%)$ обл стях [5, с. 321]. т тистично довідкові пок зники з свідчують тенденцію невеликого зрост ння площі цих земель у к рп тській і ьвівській обл стях $[4$, с. $486 ; 5$, с. 321$]$.

н лізу еколого-ст тистичних д них скл ду т цільового призн чення земель рп тського регіону кр їни можн зробити т кі висновки:

- н йбільш землемісткою є ьвівськ обл. (2 183,1 тис. г ), н йменш - ернівецьк (809,6 тис. г );

- у структурі земельного фонду ернівецької (59,8 \% від з г льної площі території), ьвівської $(59,4 \%)$ т в но- р нківської $(46,5 \%)$ обл стей перев ж ють землі сільськогоспод рського призн чення, в к рп тській - ліси т лісовкриті площі $(56,8 \%)$;

- порівняно з 1990 р. площ сільськогоспод рських угідь у володінні т користув нні всіх к тегорій господ рств зменшил ся н 8,9 \%, ріллі - н 9,9\%; н йбільше цих угідь втр тил ьвівськ обл., зокрем сільськогоспод рських - 16,6, ріллі $-15,7 \%$;

- $з$ одного боку, зрост ють темпи т обсяги з готівлі ліквідної деревини і збільшуються площі лісовідновлюв льних земель, з іншого, - порушується оптим льне співвідношення структури вікових груп лісів;

- різке збільшення площі з будов них земель прип ло н 1990-2000рр.; сьогодні ситу ція дещо ст білізув л ся. житловому будівництві перев ж є комерційне житло, незв ж ючи н великі черги н отрим ння житл, які усп дков но з р дянських ч сів.

ке явище спричинює дисб л нс: $з$ одного боку, висок в ртість житл, $з$ іншого, неспроможність купити це житло, що спричинено бідністю н селення;

- незв ж ючи н розвинену мережу природних і штучних водних об'єктів, кту льною серед екологічних проблем сьогодення, головно рівнинної території водних б сейнів регіону, є проблем якісної води.

1. ерж вн прогр м “ іси кр їни” н 2002-2015 роки // ост нов бінету іністрів кр p їни від 29 квітня 2002 р. № 581. ежим доступу: http//www. kmu. gov.ua.

2. inm ч . епресивні регіони кр їни: екологічн компонент : оногр фія. ьвів:

ім. . p нК, 2008. 288 c.

3. сновні х р ктеристики регіонів // егіони кр їни: 2 ч. $\quad . \quad$ ержкомст т, 2007. . 1. . 10-20.

4. хорон н вколишнього середовищ // егіони кр їн: 2 ч.. ержкомст т, $2004 . \quad$. 1. . 485-506.

5. хорон н вколишнього середовищ // егіони кр їни: 2 ч. .: ержкомст т, 2007. . 1. . 320-341.

6. ньків . . емельні ресурси: вч. посібник. ьвів: ім. . p нк, 2008. 272 с.

7. ільське господ рство, мисливство, лісове т рибне господ рство // егіони кр їни: 2 ч. .: ержкомст т, 2006. . 2. . 159-241. 
8. ільське господ рство, мисливство, лісове т рибне господ рство // егіони кр їни: 2 ч.. : ержкомст т, 2007. . . 2. . 169-250.

\section{STRUCTURE AND PURPOSE OF THE MAJOR CATEGORIES \\ OF LANDS OF CARPATHIAN REGION OF UKRAINE}

\section{F. Kiptach}

Ivan Franko National University of Lviv, . Doroshenko St., 41, UA - 79000 Lviv, Ukraine

The structure of basic categories of lands of the Carpathian region and modern state of their use in region was described. It were substantiated tendencies of changes of lands of a different composition and a special purpose setting.

Key words: Carpathian region, land fund, categories of lands, agricultural lands, plough-land, forests, built-up areas.

\section{- ИIIT Ч}

ввовский н цион льный университет имени в н р нко,

ул. . орошенко, 41, г. ьвов, 79000, кр ин

свещено структуру основных к тегорий земель рп тского регион . боснов но тенденции изменений земель $\mathrm{p}$ зличного сост в и целевого н зн чения.

лючевые слов : $\quad$ п тский регион, земельный фонд, к тегории земель, сельскохозяйственные угодья, п шни, лес , з строенные уч стки.

т ття н дійшл до редколегії 27.07.2009

рийнят до друку 20.09.2009 